\title{
PENINGKATAN KOMPETENSI DESAIN WEB BAGI SISWA SEKOLAH MENENGAH KEJURUAN (SMK) SECARA DARING
}

\author{
Hamidillah Ajie ${ }^{1)}$, Irma Permata Sari ${ }^{2)}$ \\ ${ }^{1,2}$ Pendidikan Teknik Informatika, Fakultas Teknik, Universitas Negeri Jakarta, \\ Indonesia \\ ${ }^{2}$ Sistem dan Teknologi Informasi, Fakultas Teknik, Universitas Negeri Jakarta, \\ Indonesia \\ e-mail: irmapermatasari@unj.ac.id
}

\begin{abstract}
Online business has been raised rapidly in recent times. This is a challenge for a web developer or web designer. According to the Bureau of Labor Statistics, job opportunities as web development are projected to grow by 27\% from 2014 to 2024. But web course material provided at Vocational high School is still limited to basic material. We know that Vocational High Schools are formed to prepare graduates who are ready to work and become a solution to unemployment problem. A programmed, it is called "Pengabdian Pada Masyarakat", gives a training to society, in our study case is Vocational high School Binakarya Mandiri 2 Bekasi. This training was held with online platform and attended by around 25 students. The results of this training are 1) $e$ commerce website products, 2) training modules, and 3) video tutorials. We can be concluded that this activity can support vocational students programming skills.
\end{abstract}

KEYWORDS: Online business, Web developer, Web designer, E-commerce

\begin{tabular}{|c|c|c|}
\hline Accepted: & Reviewed: & Published: \\
January 07 2021 & January 14 2021 & February 15 2021 \\
\hline
\end{tabular}

\section{PENDAHULUAN}

Tingginya tingkat pengangguran dan kemiskinan di Indonesia masih menjadi permasalahan yang harus segera dituntaskan oleh negara. Menurut Siaman (Aprilianty, 2013) hal disebabkan karena perbandingan antara jumlah penawaran kesempatan kerja tidak sebanding dengan jumlah lulusan atau penawaran tenaga kerja baru di segala level Pendidikan. Salah satu program yang telah dilakukan oleh pemerintah untuk mengurangi angka pengangguran tersebut telah sampai pada tingkat Kabupaten/Kota melalui Dinas Tenaga Kerja Transmigrasi dan Dinas Pendidikan salah satunya yaitu reformasi di bidang 
pelatihan dan peningkatan relevansi pelatihan yang diselenggarakan sesuai dengan kebutuhan pasar kerja, peningkatan kualitas pelatihan, dan peningkatan efisiensi pelatihan.

Program lain yang lakukan oleh pemerintah adalah melalui Kementrian Pendidikan Nasional sejak awal tahun 2005 yang mulai mengembangkan kembali peran SMK dan lulusan SMK untuk siap kerja dan siap menjadi wirausaha. SMK di Indonesia memiliki berbagai macam tujuan pembelajaran untuk menghasilkan lulusan siap kerja dan berwirausaha. Salah satu yang ada di Indonesia adalah SMK Binakarya Mandiri 2 Bekasi.

SMK Binakarya Mandiri 2 Bekasi Dibangun tahun 2005 dengan luas tanah 2500 M2 oleh tiga sekawan yaitu Drs Dodo Badjari, Drs Budi Sahudi, Drs. Ayung Sardi dauly. Yang merupakan perintis dari SMK BKM2 dibawah naungan LEMBAGA PENDIDIKAN BINAKARYA MANDIRI. SMK ini mulai beroperasi pada tahun 2007 dengan jumlah siswa baru berjumlah 286 siswa yang kemudian menjadi angkatan pertama lulusan tahun 2010. Operasional berdasarkan surat keputusan Kementerian Pendidikan dan Kebudayaan dengan No.SK.Pendirian:421.3/25-BPPT/IV/2009 - NSPN: 20257422.

SMK Binakarya Mandiri 2 Kota Bekasi memiliki sejumlah jurusan dan salah satunya yaitu jurusan Teknik Komputer dan Jaringan. Pada jurusan ini materi pengembangan web sudah diberikan pada siswa-siswa kelas X dan XI. Namun, materi yang diberikan umumnya baru sebatas pengenalan dasar-dasar pengembangan web, seperti HTML, CSS dan Javasript, dan belum sampai pada pengembangan sebuah web e-commerce.

Terkait dengan tujuan SMK, diharapkan siswa SMK tidak saja menjadi pegawai atau bekerja di sebuah perusahaan atau industri, tetapi juga mampu membuka peluang berwirausaha. Dengan meningkatan kompetensi yang dicapai, diharapkan para siswa mampu berinovasi dan menghasikan sebuah ide bisnis online dan mampu membangun website e-commerce. Oleh karena itu tim dosen dan mahasiswa dari UNJ melakukan kegiatan Pengabdian Kepada Masyarakat 2020 di sekolah ini dengan tema "Pelatihan Desian Web Bagi Siswa SMK sebagai Dasar Pengembangan Jiwa Kewirausahaan”.

\section{METODE PELAKSANAAN}

Metode dalam pelaksanaan pelatihan dilakukan dengan dengan kondisi pandemi yang melanda Indonesia sejak Maret 2020. Adanya himbauan dari pemerintah yang menyatakan bekerja dari rumah (work from home), social distancing serta penyesuaian sistem kerja bukan berarti pelayan publik dan 
103 | Peningkatan Kompetensi Siswa Sekolah Menengah

Kejuruan (SMK) Desain Web E-Commerce Secara Daring

pembelajaran dihentikan, namun semua aktivitas dilakukan dengan bantuan teknologi informasi atau secara online(Hidayatullah et al., 2020). Pelatihanpun dilakukan secara daring menggunakan platform video conference Zoom, WhatsApp, dan Classroom. Instruktur adalah dosen program Studi Pendidikan Informatika dan mahasiswa Program Studi Informatika yang sudah memiliki pengalaman di dunia industri pengembangan web. Pelatihan juga masih akan dibantu oleh sejumlah tim mahasiswa.

Pelatihan ini dilaksanakan dengan metode sinkron dan asinkron. Metode sinkron adalah pembelajaran yang dilakukan secara dari dimana pendidik dan peserta didiknya berada dilokasi yang berbeda, kemudian melakuan pertemuan di waktu bersamaan, pada room maya yang sama, misalnya video conference (Sudarsana, 2018). Sebaliknya metode asinkronus melakukan kegiatan belajar mengaja pada saat yang tidak bersamaan, misalnya melalui sebuah blog, classroom di aplikasi Google dan lain-lain. Kegiatan dalam pelatihan inipun dibagi menjadi lima tahapan:

1. Kegiatan persiapan

2. Kegiatan pembukaan

3. Kegiatan pelatihan secara sinkron

4. Kegiatan pelatihan asinkron

5. Penutupan

Peserta pelatihan adalah SMK Binakarya Mandiri 2 Kota Bekasi mengikut sertakan siswa-siswinya khususnya kelas X Binakarya Mandiri 2 Kota Bekasi. Metode pelatihan yang digunakan saat pelatihan adalah metode ceramah, praktik, tutorial, dan tanya jawab. Yang paling menarik dari kegiatan ini adalah metode praktik secara asinkron dilakukan selama seminggu dan para siswa dapat menyelesaikan projek website e-commerce yang meraka bangun sambil dibuka forum tanya jawab di grub WhatsApp. Deadline pengumpulan projek website yang dibuat dikumpulkan pada sehari sebelum penutupan berlangsung. Kemudian hasilnya diumumkan pada saat penutupan.

Berikut ini adalah defenisi singkat dari lingkup materi pelatihan yang diberikan:

\section{Website}

Website atau lebih dikenal dengan web adah sebuah laman dijejaring internet yang berfungsi untuk menyimpan dan menampilkan informasi (Kartasura, 2016). Laman tersebut merupakan kombinasi dari beberapa komponen multimedia seperti teks, gambar, audio, video, dan animasi dari 
berbagai bentuk sehingga menjadi menarik untuk diakses (Kuswanto, 2006). Sebuah website dapat diakses kapanpun dan dimanapun melalui sebuah web browser. Untuk membuat sebuah website juga membutuhkan kemampuan dalam membuat desain web, sedangkan orang yang membuat desain web tersebut disebut dengan web desainer.

\section{Desain Web}

Desain web adalah suatu istilah dalam menampilkan isi atau konten web dalam visual yang memiki nilai desain yang baik. Adapun alat atau tools yang dibutuhkan untuk melakukan praktik desain web terbagi menjadi dua, yaitu perangkat lunak (software) dan perangkat keras (hardware) (Santoso, 2019). Untuk lebih detail dapat dilihat pada Tabel 1.

Tabel 1. Alat dan Tools untuk Pelatihan Desain Web

\begin{tabular}{|l|l|l|}
\hline No & \multicolumn{1}{|c|}{ Alat (tools) } & \multicolumn{1}{|c|}{ Keterangan } \\
\hline 1. & $\begin{array}{l}\text { Perangkat Lunak } \\
\text { a. Text Editor, missal Visual Studio } \\
\text { Code } \\
\text { b. Browser, seperti Chrome atau } \\
\text { Mozzila }\end{array}$ & $\begin{array}{l}\text { Editor digunakan untuk } \\
\text { pengujian dan penulisan code }\end{array}$ \\
\hline 2. & $\begin{array}{l}\text { Perangkat keras } \\
\text { a. 1 unit PC/Laptop } \\
\text { b. Mouse, monitor, keyboard } \\
\text { c. Ponsel }\end{array}$ & $\begin{array}{l}\text { Spesifikasi PC standar } \\
\text { minimal RAM 4G, HDD 256 } \\
\text { GB }\end{array}$ \\
\hline
\end{tabular}

Pembuatan aplikasi berbasis web pastinya tidak akan lepas dari mendesain template, yang mengharuskan programmer meluangkan banyak waktu untuk menuliskan sintak sintak CSS (Rosid \& Jakaria, 2016). Sintaks CSS digunakan untuk membuat tampilan web menjadi lebih bagus dan menarik. Saat ini banyak sekali tools atau Framework CSS yang dapat dimanfaatkan untuk mempercepat pengerjaan desain web. Dalam pelatihan ini menggunakan framework wordpress 5.5.1.

\section{E-commerce}

E-commerce atau electronic commerce merupakan perdagangan yang dilakukan secara elektronik (Wahyuningrum \& Januarita, 2014). E-commerce dapat secara menyeluruh dapat diartikan sebagai didefenisikan pembelian dan penjualan barang dan jasa, kemudian pelayanan pelanggan, kolaborasi dengan mitra bisnis dan transaksi dalam perusahaan dan aktifitas terkait lainnya. 
105 | Peningkatan Kompetensi Siswa Sekolah Menengah

Kejuruan (SMK) Desain Web E-Commerce Secara Daring

\section{HASIL DAN PEMBAHASAN}

Siswa-siswi SMK Binakarya Mandiri 2 Kota Bekasi yang mengikuti pelatihan ini dipilih berdasarkan tingkat kompetensi dasar terhadap proses pengembangan web, dan berdasarkan tingkat motivasi mereka terhadap jenis wirausaha online. Seleksi dilakukan oleh perwakilan guru SMK Binakarya Mandiri 2 Kota Bekasi. Metode pelatihan menitikberatkan kepada praktek pengembangan web, mengingat para peserta sudah mengenal dasar-dasar pengembangan web. Untuk dapat lebih meningkatkan keefektivitasan hasil pelatihan, materi yang diberikan adalah penyelesaian kasus pengembangan bisnis online dengan menggunakan sejumlah framework pengembangan web yang banyak digunakan saat ini. Berikut ini tapahan kegiatan Pengabdian Kepada Masyarakat yang dilakukan:

\section{Kegiatan persiapan}

Rapat persiapan kegiatan ini meliput beberapa kegiatan misal: menyurati pihak sekolah, mengumpulkan data-data peserta, menyiapkan kegiatan pada hari H kegiatan, menyiapkan materi dan modul. Rapat dilakukan oleh dosen-dosen Program Studi Pendidikan Teknik Informatika dan Komputer (PTIK) melalui platform Zoom. Salah satu upaya yang tak kalah penting untuk pelatihan ini adalah menyiapkan materi, tools dan aset yang dapat digunakan oleh peserta saat pelatihan. Gambar 1 berikut ini adalah bukti kesiapan tim P2M Desain Web.

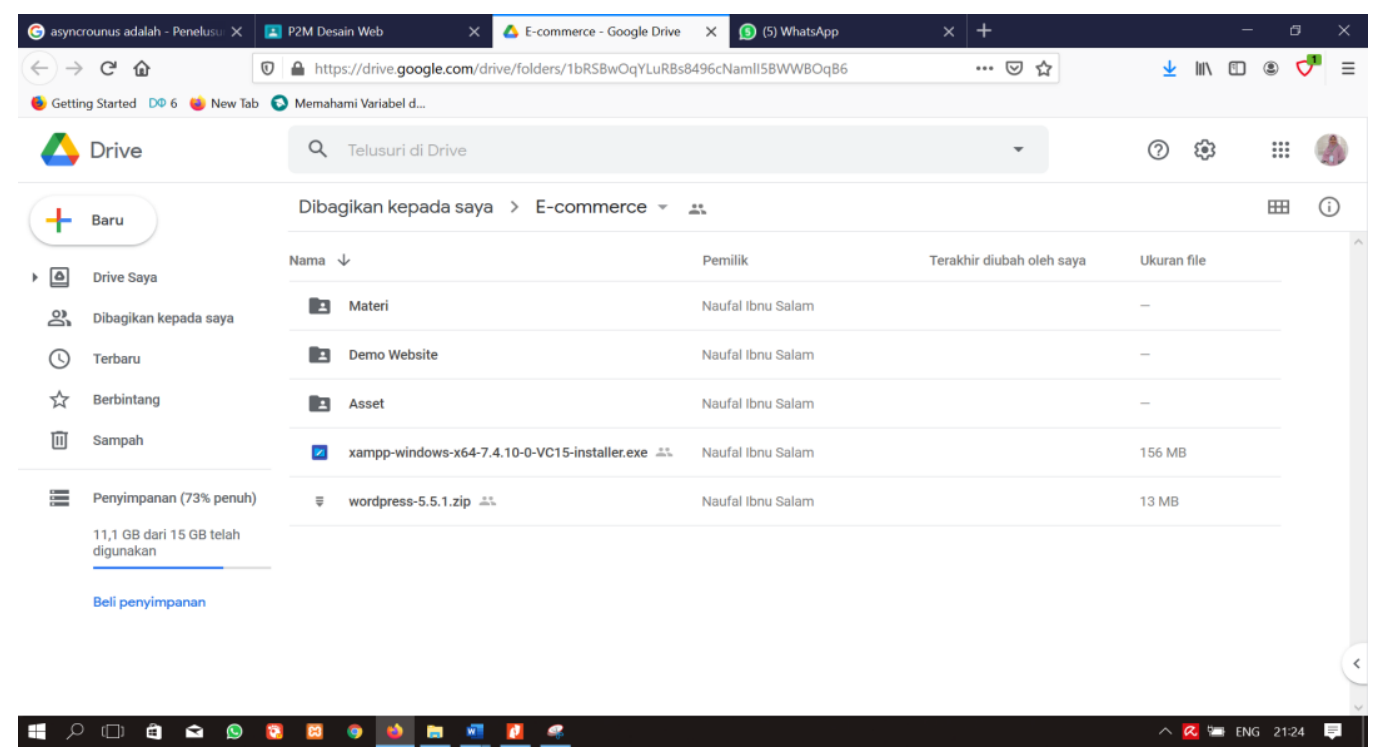

Gambar 1. Google drive materi, tools dan aset-aset pelatihan desain web 


\section{Pembukaan Kegiatan P2M secara serentak di Prodi PTIK UNJ}

Kegiatan pembukaan P2M secara serentak di Prodi PTIK UNJ bersama kelompok kegiatan P2M lainnya. Kegiatan pembukaan dilaksanakan pada hari Sabtu, 19 September 2020 pada pukul 08.00 - 11.00 WIB dengan menggunakan platform video conference (vicon) Zoom yang dihadiri dan dibuka oleh Koordinator Program Studi PTIK. Setelah kegiatan pembukaan selesai dilanjutkan dengan Isoma dan pada pukul 13.00 masing-masing peserta kembali pada kelompok pelatihan masing-masing. Gambar 2 berikut ini adalah bukti kegiatan pembukaan Kegiatan P2M.

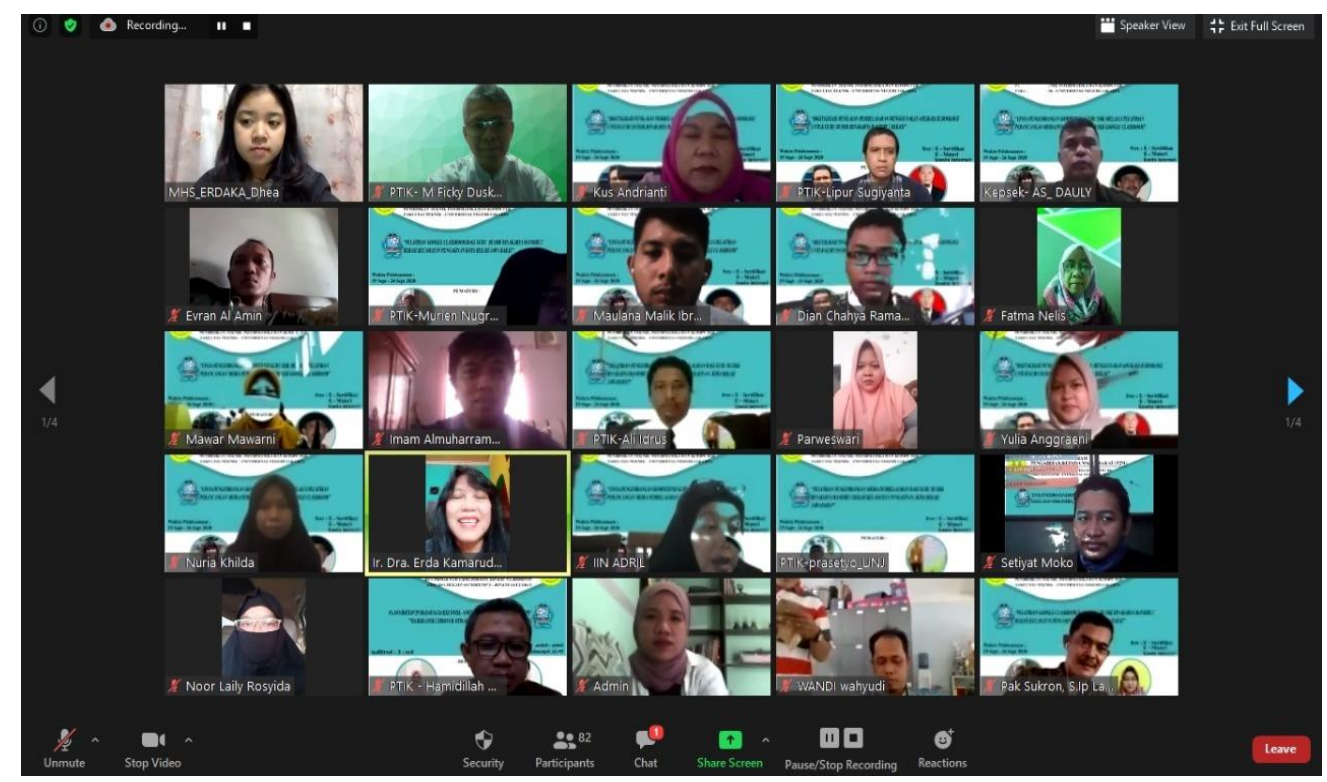

Gambar 2. Kegiatan Pembukaan P2M PTIK UNJ

\section{Kegiatan pelatihan secara sinkronus}

Kegiatan pelatihan secara sinkronus dilakukan melalui platform Zoom dengan penyampaian materi oleh tim pengusul. Kegiatan ini dilaksanakan pada hari Sabtu, 19 Oktober 2020 pukul 13.00 - 16.00. Berikut ini bukti hasil kegiatan dapat terlihat pada Gambar 1, 2, 3 dan 4 berikut.

Gambar 3 adalah foto bersama sebelum memulai kegiatan pelatihan. Sedangkan Gambar 4 adalah dokumentasi saat Pemateri 1 menyampaikan materi terkait dengan internet dan web. Kemudian dilanjutkan dengan pemaparan materi dengan tema Web E-commerce oleh pemateri kedua, dapat terlihat pada Gambar 5. Kemudian baru masuk ke materi inti yaitu desain web oleh tim dosen dan dibantu oleh oleh tim anggota mahasiswa, seperti pada Gmabar 6. Selama kegiatan berlangsung peserta nampak antusias sebab 
107 | Peningkatan Kompetensi Siswa Sekolah Menengah

Kejuruan (SMK) Desain Web E-Commerce Secara Daring

materi ini sangat menarik minat siswa-siswi SMK Binakarya Mandiri 2 Kota Bekasi.

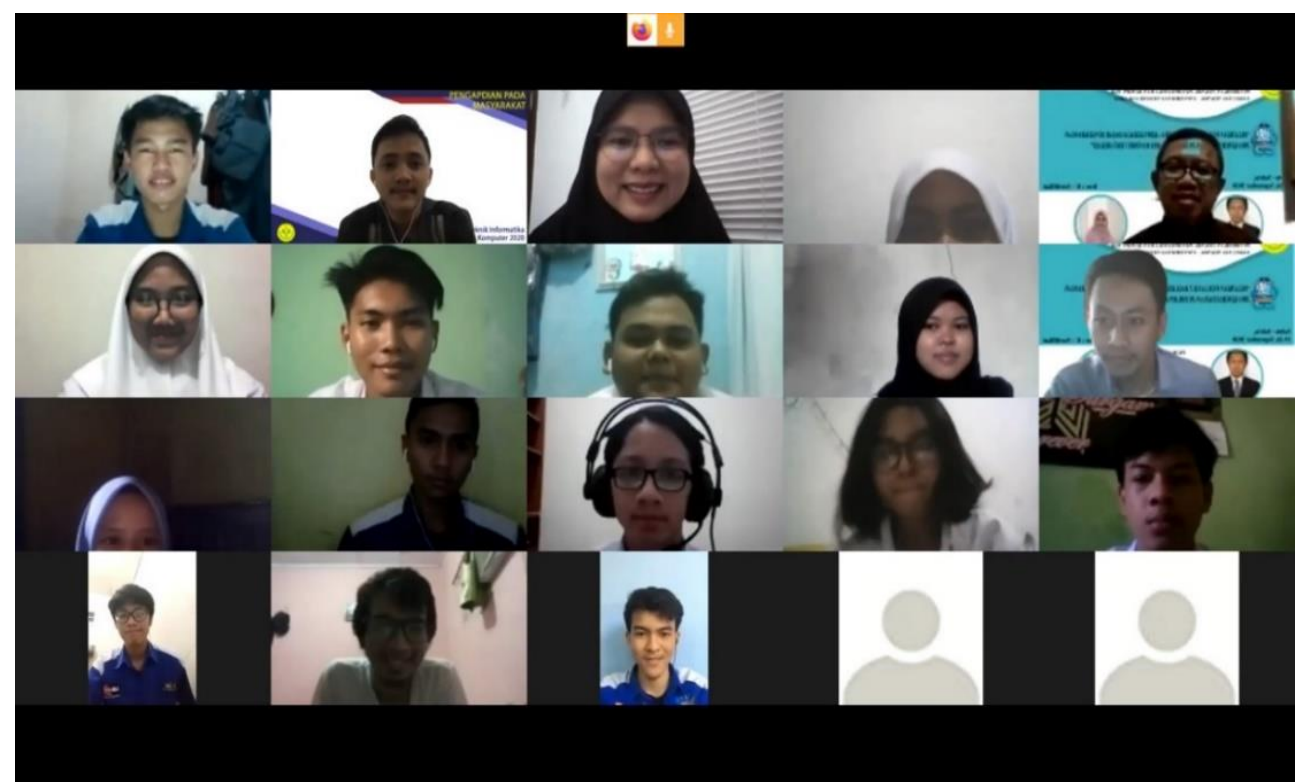

Gambar 3. Foto bersama peserta pelatihan

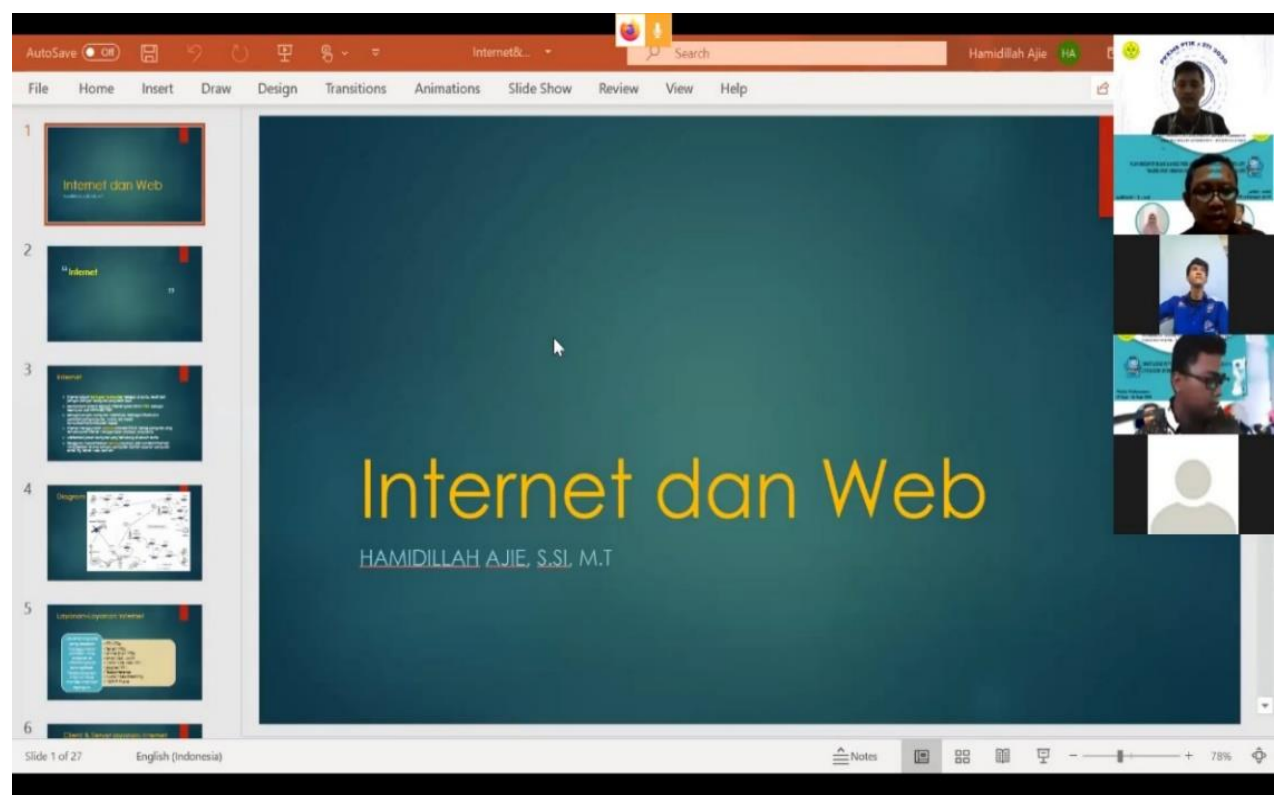

Gambar 4. Pemaparan materi tentang website 


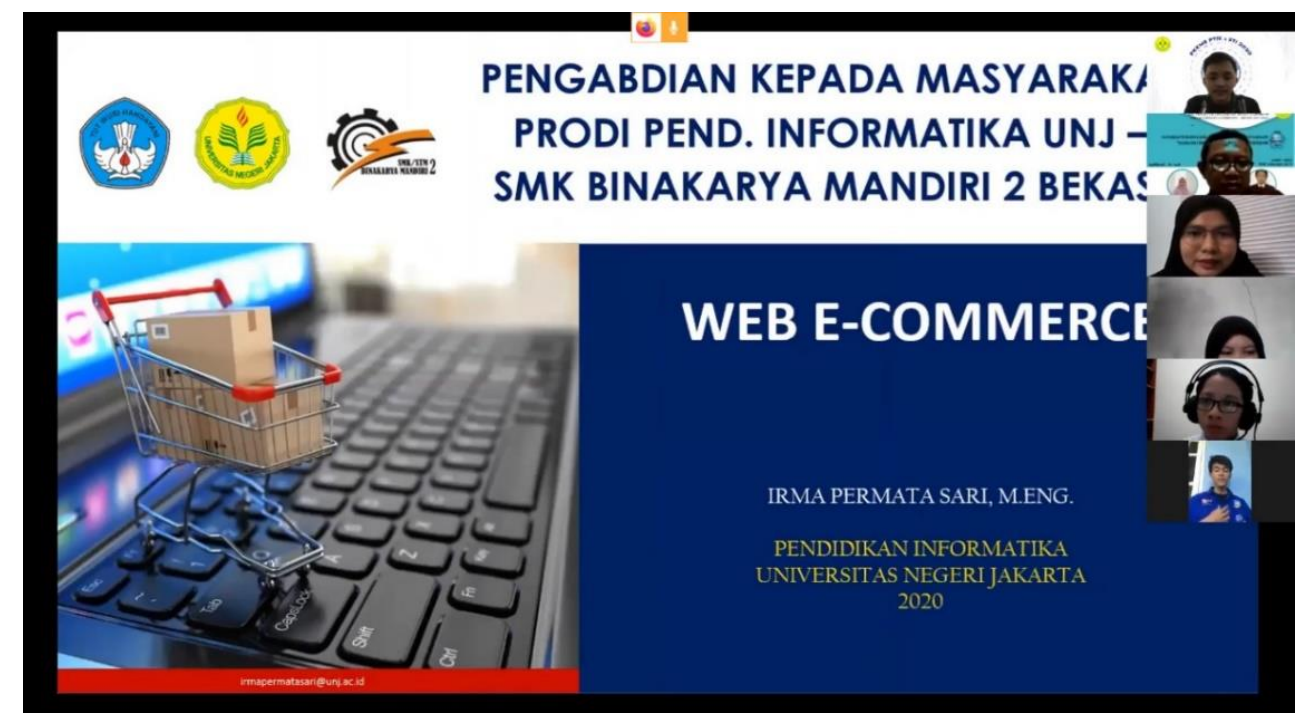

Gambar 5. Pemaparan materi tentang web e-commerce

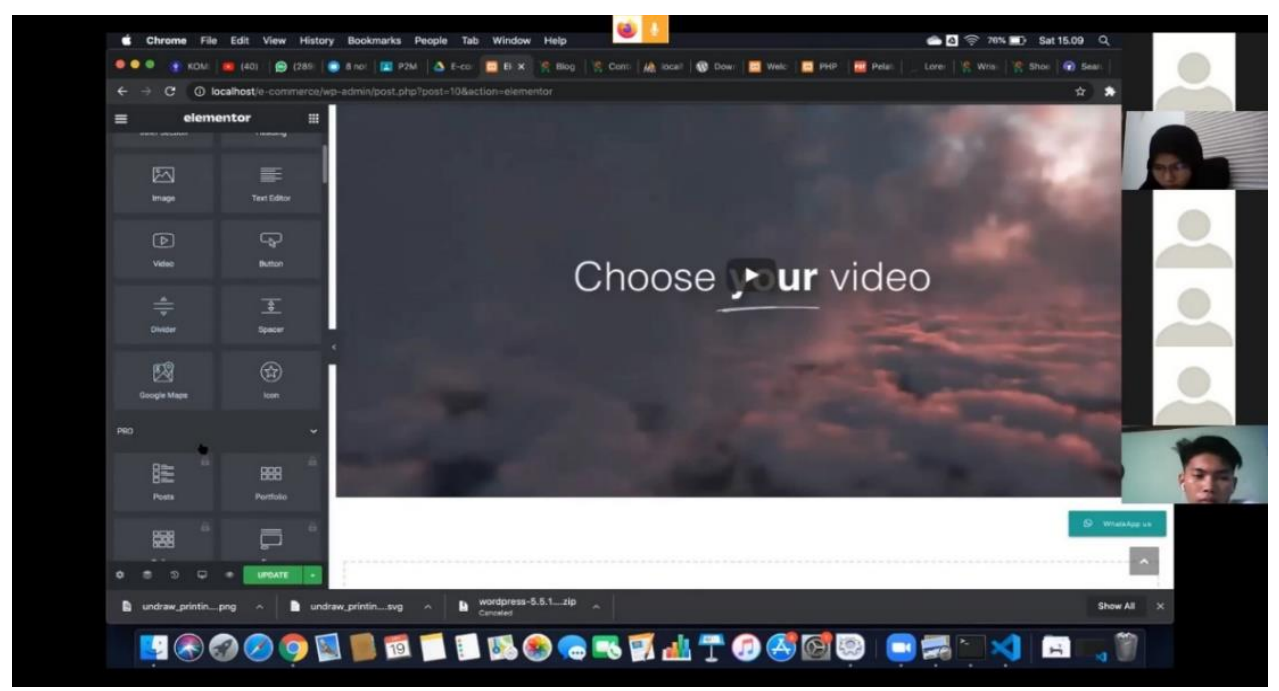

Gambar 6. Mendemokan materi praktik desain web

4. Kegiatan pelatihan secara asinkron

Kegiatan pelatihan pada tahapan dilakukan secara asinkron atau tanpa melalui platform vicon Zoom, namun diganti dengan media Google Classroom, video tutorial dan chat di WhatsApp Grup untuk kegiatan tanya jawab. 
109 | Peningkatan Kompetensi Siswa Sekolah Menengah Kejuruan (SMK) Desain Web E-Commerce Secara Daring

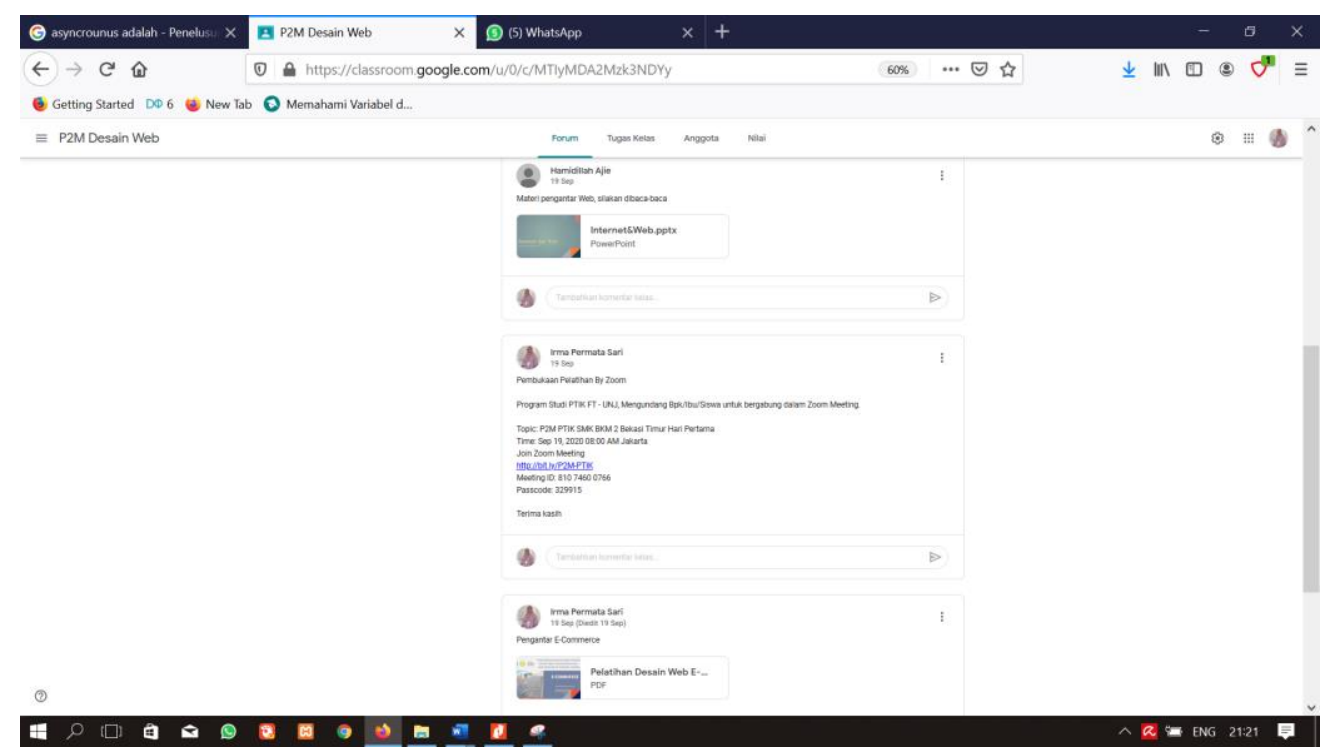

Gambar 7. Google Classroom Pelatihan

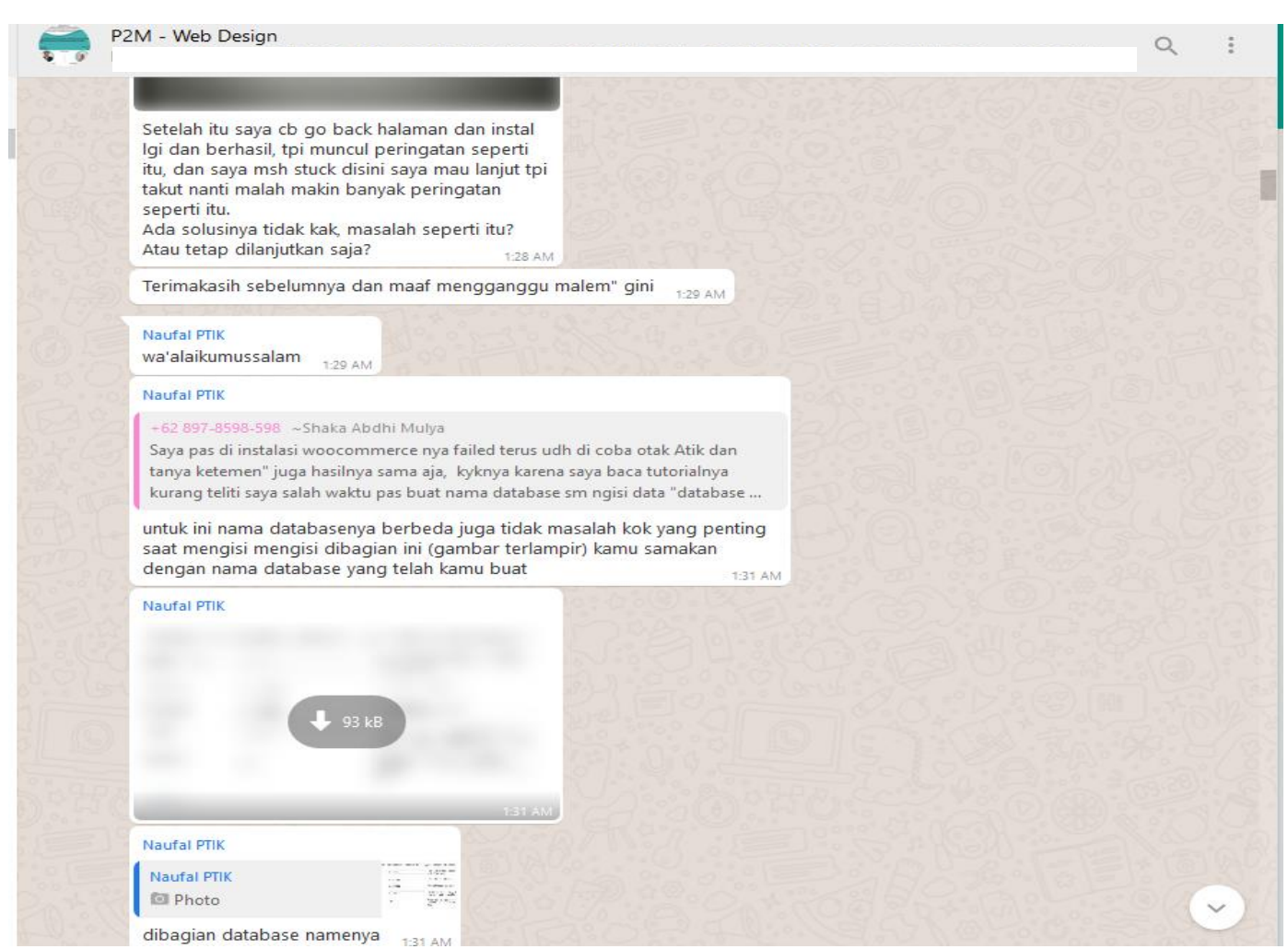

Gambar 8. Tanya jawab via WhatsApp grub P2M desain web 


\section{Penutupan kegiatan Pengabdian Kepada Masyarakat}

Kegiatan penutupan P2M juga dilakukan secara serentak bersama kelompok kegiatan P2M lainnya. Kegiatan pembukaan dilaksanakan pada hari Sabtu, 26 September 2020 pada pukul 08.00 - 10.00 WIB dengan menggunakan platform video conference (vicon) Zoom oleh Koordinator Program Studi PTIK dan masing-masing ketua masing-masing kelompok memberikan pelaporan dan evaluasi kegiatan.

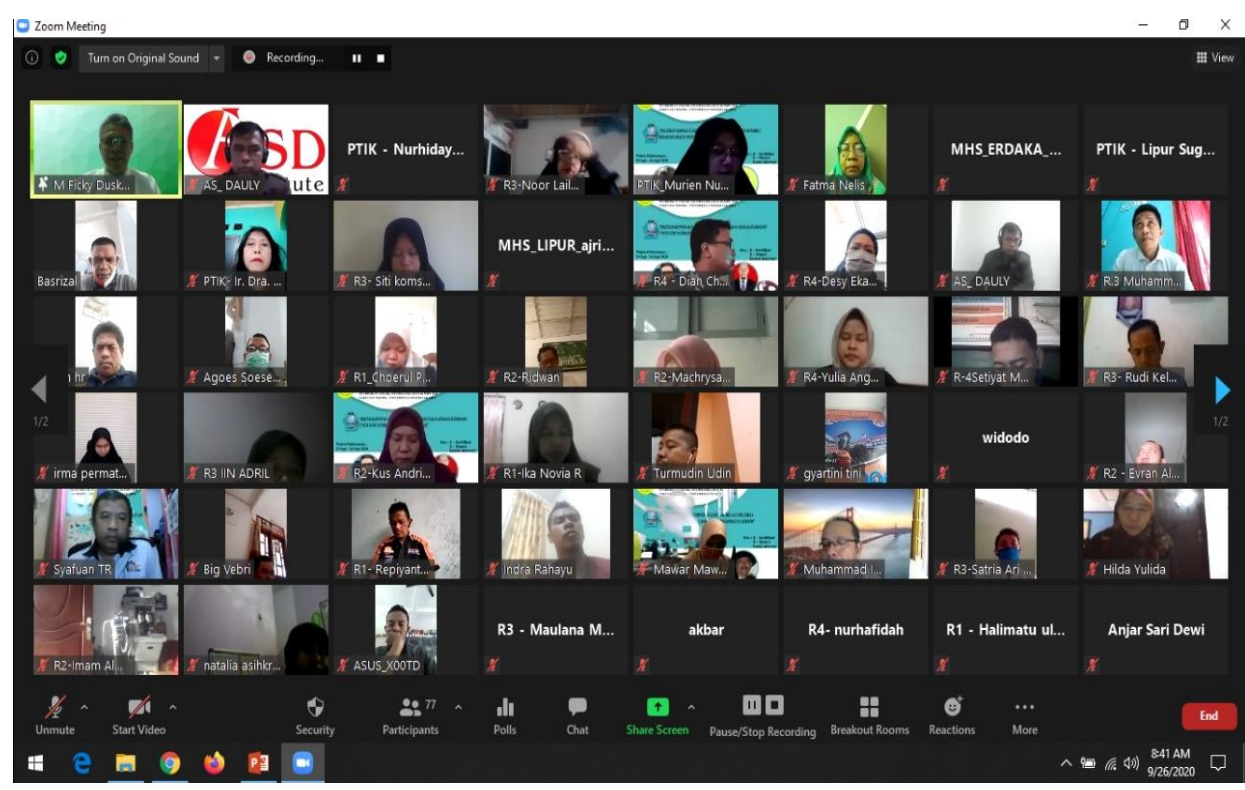

Gambar 9. Penutupan Kegiatan P2M PTIK UNJ 2020

\section{SIMPULAN}

Berdasarkan hasil kegiatan Pengabdian Kepada Masyarakat yang dilakukan dapat disimpulkan bahwa kegiatan pelatihan desain web bagi siswaSMK Binakarya Mandiri 2 Kota Bekasi telah dilakukan dengan metode sinkron dan asinkron melalui platform seperti Zoom, Google Classroom dan Grup WhatsApp. Adanya penambahan materi tentang e-commerce berkaitan dengan materi kewirausahaan sangat cocok buat para siswa agar tetap bersemangat dalam menyelesaikan proyek desain web yang ditugaskan. Beberapa hal yang dapat disarankan terkait dengan kegiatan Pengabdian Kepada Masyarakat ini kepada peneliti berikutnya adalah dengan menambah waktu pelatihan dengan memberikan kesempatan untuk presentasi hasil desain web yang dibuat serta memberikan masukan terhadap desainnya. 
111 | Peningkatan Kompetensi Siswa Sekolah Menengah

Kejuruan (SMK) Desain Web E-Commerce Secara Daring

\section{DAFTAR RUJUKAN}

Aprilianty, E. (2013). Pengaruh kepribadian wirausaha, pengetahuan kewirausahaan, dan lingkungan terhadap minat berwirausaha siswa SMK. Jurnal Pendidikan $\quad$ Vokasi, 2(3), 311-324. https://doi.org/10.21831/jpv.v2i3.1039

Hidayatullah, S., Khouroh, U., \& Windhyastiti, I. (2020). Jurnal Teknologi dan Manajemen Informatika Implementasi Model Kesuksesan Sistem Informasi DeLone And McLean Terhadap Sistem Pembelajaran Berbasis Aplikasi Zoom Di Saat Pandemi. 6(1), 44-52.

Kartasura, M. (2016). Penerapan Teknologiweb Sekolah Bagi SMP Dan SMA Muhammadiyah Kartasura. 1, 39-52.

Kuswanto, H. (2006). Analisis Prinsip Layout and Composition pada Web Design Perusahaan PT . Bank Rakyat Indonesia , Tbk dan PT . FIF Group berdasarkan Buku "The Principle of Beautifull Website Design ( 2nd Edition ) By Jason Beaird ."

Rosid, M. A., \& Jakaria, R. B. (2016). Implementasi Framework Twitter Bootstrap Dalam Perancangan Aplikasi Penerimaan Mahasiswa Baru Berbasis Web. Kinetik, 1(3), 129. https://doi.org/10.22219/kinetik.v1i3.121

Santoso, M. F. (2019). Teknik Responsive Web Design Bootstrap 4 Serta Penerapannya Dalam Rancang Bangun Layout Web. Jurnal Pilar Nusa Mandiri, 15(1), 61-68. https://doi.org/10.33480/pilar.v15i1.101

Sudarsana, I. K. J. S. I. P. H. Y. S. N. P. S. I. M. R. K. B. R. P. K. N. A. (2018). Teknologi dan Aplikasinya dalam Dunia Pendidikan 1.

Wahyuningrum, T., \& Januarita, D. (2014). Perancangan Web e-Commerce dengan Metode Rapid Application Development ( RAD ) untuk Produk Unggulan Desa. 2014(November), 81-88. 